\title{
Modelling the effects of sea-level rise and sediment budget in coastal retreat at Hermenegildo Beach, Southern Brazil
}

\author{
Salette Amaral de Figueiredo ${ }^{1}$, Lauro Julio Calliari ${ }^{1}$, Arthur Antonio Machado ${ }^{1}$ \\ ${ }^{1}$ Universidade Federal do Rio Grande, Instituto de Oceanografia \\ (km 8, Av. Itália - Carreiros, Rio Grande - RS - 96.201-900- Brazil) \\ *Corresponding author: saletteoc@gmail.com
}

\section{Abstract}

Climate change effects such as accelerated sea-level rise, wave climate alteration and disturbances on sediment-budgets are anticipated to lead to a range of adverse impacts in coastal regions around the world. A rise in sea-level is expected to cause shoreline recession, and a sediment deficit can have a similar effect. Since large uncertainties exist in relation to sea-level rise rates and sediment budgets, it is relevant to determine how sensitive the coast is to each of these disturbances. In this context, this paper provides a quantitative evaluation of each of these parameters in terms of modeled coastal recession through risk-based assessments using an aggregated coastal model, the DRanSTM (Dilating Random Shoreface Translation Model). In each separate computer simulation, a sediment budget and a sea-level scenario were set for an erosional coastal stretch: Hermenegildo Beach, Rio Grande do Sul state in southern Brazil. Effects of changes in wave climate were not directly considered in this study. However, indirect measures of such changes should be reflected on coastal sediment budgets. Simulation results demonstrate that under present-day sea-level rise rates, sediment deficit exerts control over coastal recession. Conversely, under the higher forecasted sea-level rise for the year 2100 , mean shoreline recession will be dictated by sea-level rise, considering historical sediment deficit will be sustained.

Descriptors: Coastal erosion, Shoreline behaviour, Forecast, Climate change.

\section{Resumo}

Dentre alguns dos efeitos esperados das mudanças climáticas previstas para o próximo século podemos citar: a subida acelerada do nível médio do mar e as modificações no clima de ondas, acompanhadas de alterações no balanço sedimentar, os quais causarão impactos adversos nas regiões costeiras de todo o mundo. $\mathrm{O}$ aumento do nível médio do mar causa retrogradação costeira; um déficit sedimentar pode ter um efeito semelhante. De forma geral, ainda existem grandes incertezas tanto em relação às taxas projetadas de subida do nível do mar, quanto às estimativas do balanço de sedimentos, sendo assim relevante determinar quão sensível é a costa a alterações em cada um desses fatores. Neste contexto, este artigo visa fornecer uma avaliação quantitativa dos efeitos da variação de cada um destes parâmetros através de avaliações baseadas em risco da distância de recuo da linha de costa, usando um modelo costeiro agregado, o DRanSTM (Dilating Random Shoreface Translation Model). Em cada simulação computacional separada, um balanço sedimentar e um cenário de elevação do nível do mar foram definidos para o trecho costeiro que inclui a Praia do Hermenegildo, Rio Grande do Sul, Brasil. Efeitos das alterações no clima de ondas não foram considerados diretamente neste estudo. Entretanto, medidas indiretas de tais mudanças são refletidas no balanço sedimentar costeiro estimado. Os resultados das simulações demonstram que sob as atuais taxas de subida do nível médio do mar, o déficit de sedimentos exerce controle sobre a retrogradação costeira. Por outro lado, sob a condição de subida acelerada do nível do mar prevista para o ano 2100, a retrogradação média da costa será ditada pela elevação do nível do mar, considerando que déficit histórico de sedimentos será mantido.

Descritores: Erosão costeira, Linha de costa, Balanço sedimentar, Predição, Mudanças climáticas. 


\section{INTRODUCTION}

Sea-level fluctuations associated with natural glacioeustatic cycles have been responsible for changes in coastline configuration, including coastal progradation and recession under rising, still stand and even under receding conditions (Curray, 1964; Roy et al., 1994). The cycles of sea-level changes are widely assumed to be accompanied by sediment budget adjustments and with shoreface profiles pursuing a dynamic equilibrium state (Roy et al., 1994). As a result of these cycles the coast has been and still is engaged in constant modification and reshaping. This is a natural and continuous process of adjustment to the changes that occur in external drivers, which can vary through time and spatial scale, and that affect geomorphological features (Cowell et al., 1999; Cowell et al., 2003a).

More recently increased greenhouse gases emissions into the atmosphere have caused significant alterations to global climate, and more specifically causing global warming. As a result of rising temperatures, sea-level has been rising worldwide (Rahmstorf, 2007; Church et al., 2009; Field et al., 2014). Nonetheless, sea-level rise projections have changed markedly since IPCC (Intergovernmental Panel on Climate Change) published its First Assessment Report (AR1) in 1990, when sea-level was predicted to rise just above a meter by 2100 , followed by more optimistic projections sitting below one meter (AR2, AR3, AR4 and AR5) (Oppenheimer and Alley, 2016). Recent studies using a model coupling ice sheet and climate dynamics demonstrates that Antarctica has the potential to contribute more than a meter of sea-level rise if emissions continue unabated (DeConto and Pollard, 2016), or even exceeding $2 \mathrm{~m}$ by 2100 (Oppenheimer and Alley, 2016).

As a consequence of rising sea-levels shoreline is expected to have an upward and landward shift of the active profile causing coastline recession (Bruun, 1962). Shoreline retreat prediction is one of the most critical questions for coastal zone management planning and for impacts assessment (Simeoni and Corbau, 2009). The impact of rising sea-levels on coastal areas is inevitable; however, the degree that it will affect different locations around the globe will very much depend on site specific geo-morphodynamic characteristics. Even though, there is a common sense amongst most world researchers towards the fact that sea-level is rising, its rising rates and the extent of regional/local impacts are still subject of dispute.
Besides that, it is possible that under climate change conditions alteration of wave climate may have direct implications for alongshore sediment transport in future, complicating forecasts of coastal response to sea-level rise, as demonstrated in previous studies (e.g., List et al., 1997). Hence, shoreline position may be a result of other factors besides sea-level rise, such as changes in storm frequency and intensity, which modify coastal sedimentary budgets and can cause shoreline recession or progradation. Yet producing estimates of sediment budgets with confidence is still very challenging (Rosati, 2005).

Nevertheless, the objective of this study is not focused on directly quantifying changes in wave climate alteration, but to uncover sediment budget relative importance in relation to sea-level rise rates in influencing shoreline position forecasts. Roy et al. (1994, p.169) exposed the problematic involving sea-level changes and sediment budget for understanding large scale coastal evolution by saying: "The dichotomy between the roles of changing sea-level on the one hand and the sand budget imbalances on the other, which forms the basis for understanding coastal evolution, becomes blurred when the two factors are small and act together." Several model simulations of coastal response under rising sea-levels using the morphokinematic model, the STM (Shoreface Translation Model), demonstrated that variations on the inherited shoreface morphology (Kinsela et al., 2016), as sea-level, behavior wave climate and sedimentary regime influence coastal evolution in the long term. The embayed highstand coast of southeast Australia features a diverse range of coastal sand barriers, suggesting varying depositional responses to Holocene environmental conditions. In particular, the varying chronologies of prograded-barrier strandplains along a passive margin, with a predominantly autochthonous sedimentary regime, raises questions about relative sea-level change, and sediment sharing within and between compartments during the Holocene. Kinsela et al. (2016) apply a detailed geological data and geochronology from the Holocene prograded-barrier system at Tuncurry, within a morphodynamic modelling approach, to investigate the depositional response of the coastal system to possible drivers of strandplain growth, including sediment budgets. Along the RS coast, Dillenburg et al. (2000) demonstrated that sediment budget have also played an important role in defining the mode that coastal barriers evolved during the Holocene. However, the relative contribution of sea-level rise under 
climate change rates versus sediment deficit in coastal behaviour has not yet been quantified.

The main objective here is to evaluate the effects of sediment budget and sea-level in coastal response, we chose a coastal sector that is currently under severe erosion rates, Hermenegildo Beach, Rio Grande do Sul State, Southern Brazil (Figure 1). In that context we ask the following questions: How much of current shoreline retreat at Hermenegildo Beach is due to sea-level rise? How much is due to sediment deficit? At which rate sealevel needs to rise in order to control coastal recession in the area? These are critical questions to a robust ability to predict future coastal responses under variable sea-level rise rates along the study area and that can help understand coastal behaviour at other similar coastal sandy barriers around the world. A quantitative evaluation of how critical uncertainties in relation to such parameters really are for coastal response will provide more transparent impact projections, which will assist in better decision making for coastal management and planning, as well as for the development of adaptation strategies under climate change conditions.

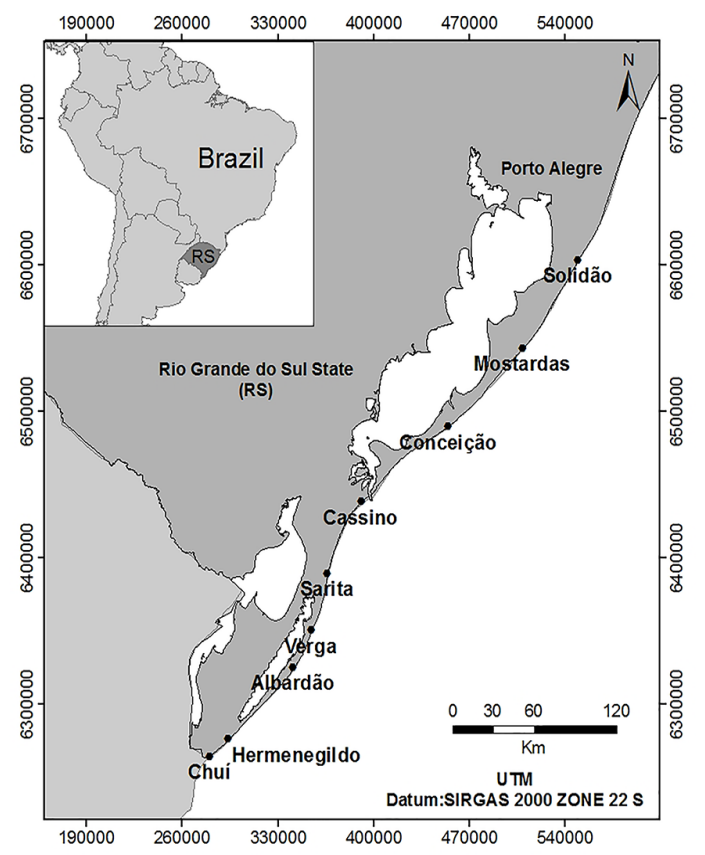

Figure 1. Study area with Hermenegildo Beach location along Rio Grande do Sul state coastline, also showing location of main lighthouses and beaches.

\section{STUDY AREA CHARACTERIZATION}

The Rio Grande do Sul state (RS) coast is a wave dominated, $620 \mathrm{~km}$ long gently undulating sand barrier, orientated SW-NE. Tides present mean amplitude of $0.31 \mathrm{~m}$, characterizing the environment as microtidal with semidiurnal tides, which play a secondary role in coastal hydrodynamics (Möller et al., 1996). Offshore wave climate based on WW3, characterizes the southern Brazilian region with a mean wave height between $2-4 \mathrm{~m}$ and periods of 7.6 to $8.2 \mathrm{~s}$ (Pianca et al., 2010). Modeling experiments on wave climate determination for the region (Cuchiara et al., 2009) and the interaction of these banks with the flow and waves. The statistical analysis of existent data on the wave climate throughout the SBS indicates that the predominant wave directions are $100^{\circ}$ and $160^{\circ}$ (E-SE indicate that the predominate wave directions are E-SE, with wave heights varying between 1 and $1.5 \mathrm{~m}$. Storms from the southern quadrant induce storm surges which can reach $1.9 \mathrm{~m}$ amplifying significantly the erosion effects over the shoreline (Parise et al., 2009). Net littoral drift along the Rio Grande do Sul coast is toward northeast (Tomazelli and Willwock, 1992; Toldo Jr et al., 2013).

In the long term geomorphological setting, Holocene barriers along the RS state have evolved in such a way that transgressive and regressive barriers coexist (Dillenburg et al., 2000). These barriers were formed in the last $7 \mathrm{Ka}$, controlled by alternate conditions of positive and negative sediment budgets along the coast, which in turn are related to gentle coastal embayments, where regressive barriers develop, and steeper coastal projections, with transgressive ones (Dillenburg et al., 2000; Martinho et al., 2009).

Most of RS coastline is currently stable or accreting. Dillenburg et al. (2000) using STM simulations provided a good basis to estimate the long-term sediment budgets within coastal embayments and projections along the RS coast. According to the author, during the last $5 \mathrm{Ka}$, the erosion of two large coastal projections would have added $1.727 .500 \mathrm{~m}^{3} \cdot \mathrm{yr}^{-1}$ to the coastal re-entrances. Along these two coastal projections are located Hermenegildo Beach, in the south coast and Conceição Lighthouse Beach in the central coast, with considerably high erosion rates.

This study was conducted at Hermenegildo Beach sector, a $10 \mathrm{~km}$ coastal stretch with critical urbanization/ erosion problems located at the southern sector of Rio Grande do Sul state (RS). The area is characterised by long term erosion being classified as a transgressive 
barrier type (Dillenburg et al., 2000; Lima et al., 2013). Initially, the barrier was controlled by sea-level rise during the Postglacial Marine Transgression (10 - 6.7 cal Ka BP), which ended at approximately 6 e 5 cal ka, when transgression starts being controlled by a negative sediment budget of the beach system, despite being in a period of an overall slow sea-level fall of approximately 2 m until present (Lima et al., 2013).

Inadequate urbanization along the last 40 to 50 years at Hermenegildo Beach, occupying areas of the active dune and beach may have exacerbated erosion problems by limiting sediment availability for coastal protective response. The sector is also subject to recent high rates of erosion with destruction of the properties even during moderate storms. For that reason, the region was classified as a priority area for management planning and protection (Esteves, 2004). The overall projected rates of shoreline recession provided for Hemenegildo Beach raise a red flag for future erosion intensification, and justifies our interest in further investigating this location over other stretches of the same coastal sand plain currently under aggradation or progradation.

\section{MATERIAL AND METHODS}

The analysis of main controls on coastal recession, sediment deficit and sea-level rise, have been considered with the application of an aggregated coastal model in its stochastic version, the RanSTM (Random Shoreface Translation Model) (Cowell, et al., 1992; Cowell et al., 2003a; Cowell et al., 2006). The model applied here accounts for a range of input parameter values including sea-level change and sediment budget: equilibrium, supply or loss. It differs from the traditional Bruun Rule (Bruun, 1962; Dean and Maurmeyer, 1983), commonly used to predict effects of sea-level rise on beaches, which is in essence a form of geometric mass-conservation model, criticized for its restrictive assumptions (Cooper and Pilkey, 2004); since it allows relaxation of some of the assumptions, particularly in relation to sediment budgets.

The standard Bruun Rule (Bruun, 1962) provides estimates of coastal response to sea-level impacts to a first approximation. Higher approximations, as those provided by RanSTM, incorporate refinements across a wider range of more realistic conditions, because it is possible to account for sediment exchanges (e.g. cross-shore, alongshore and transgressive dune) via sediment budget parameter (Cowell et al., 2006). For that reason it has been widely applicable on coastal regions subject to strong alongshore and crossshore sediment exchange component (Dillenburg et al., 2000; Cowell et al., 2003b; Cowell and Thom, 2006; Cowell et al., 2006; Figueiredo, 2013). Horizontal and vertical translation of the shoreface is governed by changes in sea-level $(S)$, substrate geometric parameters $(P)$, as well as through net gains or losses of sediment, sediment budget volume $(V)$ (Cowell et al., 2003a). Thus coastal recession, $\mathrm{R}$, is described by equation 1 below:

$$
R=f\left(\frac{d S}{d t}, \frac{d P}{d t}, \frac{d V}{d t}\right) \quad \text { Eq. } 1
$$

Simulations aimed at quantifying the effects of changes in sediment budgets, by exploiting the uncertainty associated with such estimates, and their relative influence on coastal recession under variable sea-level conditions. Storm intensity and frequency, as well as changes in wave climate, have not been assessed directly in the present application. Nonetheless, wave climate was indirectly accessed via depth of closure, which is a crucial geometric parameter in RanSTM for defining the initial substrate morphology for simulations.

Sediment budget parameter (net gains or losses) (Table 1) was calculated using a combination of medium term historical data (Albuquerque et al., 2013) and sequential beach profile data (Figure 2), as well as, with the possibility of equilibrium sediment budget (Volume $=0$ ). Medium term shoreline change estimates were based on aerial photographs and satellite images using urbanization limit as baseline (1947-2012) from Albuquerque et al. (2013), indicated that this coastal sector has been receding at a rate of $1.68 \mathrm{~m} . \mathrm{yr}^{-1}$. Sequential beach profile data used was based in 2 years of monitoring (2010-2012) (Figure 2) using dune toe as a shoreline position indicator, which points out rates of shoreline recession of $3 \mathrm{~m} \cdot \mathrm{yr}^{-1}$. Depth of closure for upper shoreface $\left(h_{c}\right)$ was defined for practical

Table 1. Range of sea-level rise and sediment-budget values considered within model forecasts.

\begin{tabular}{lccc}
\hline & Lower & Modal & Upper \\
\hline Historical Sediment deficit $\left(\mathrm{m}^{3} \cdot \mathrm{m}^{-1} \cdot \mathrm{yr}^{-1}\right)$ & 0 & -1687 & -3013 \\
Sea-level present-day $(\mathrm{m})$ (by the year 2100) & 0.08 & 0.08 & 0.08 \\
Sea-level rise rates (m) (control) & 0.09 & 0.12 & 0.16 \\
Sea-level rise (m) RPC2.6 scenario (by the year 2100) & 0.28 & 0.44 & 0.61 \\
Sea-level rise (m) RPC8.5 scenario (by the year 2100) & 0.52 & 0.74 & 0.98 \\
\hline
\end{tabular}




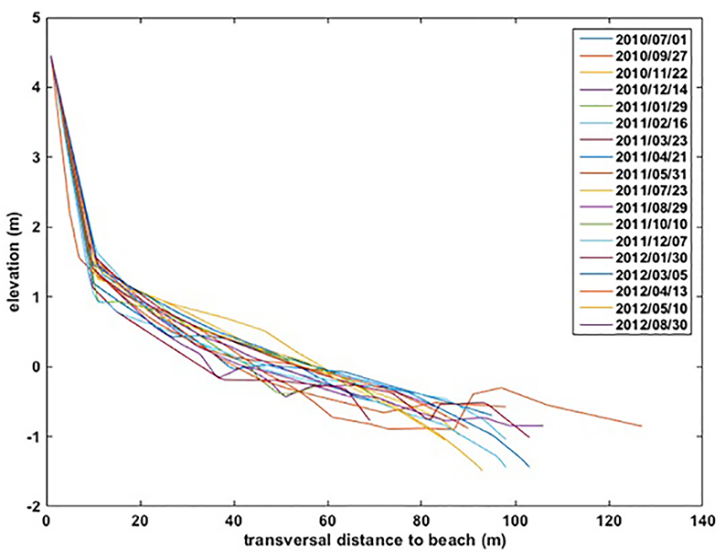

Figure 2. Sequential beach profiles from July 2010 up to August 2012.

purposes by Hallermeier (1981), as where vertical changes are less than $0.3 \mathrm{~m}$ during a typical year, and calculated using equation 2. Measured dune height $\left(h_{d}\right)$ is $4.6 \mathrm{~m}$, and calculated depth of closure $\left(h_{c}\right)$ is $7.4 \mathrm{~m}$, with a mean significant wave height of $1.5 \mathrm{~m}$.

$$
h_{c} \approx 2 \bar{H}_{s i g}+11 \sigma \quad \text { Eq.2 }
$$

where,

$\bar{H}_{\text {sig }}$ is the mean annual significant wave height (m),

$\sigma$ is the standard deviation of mean annual significant wave height.

Sediment budget volume $\left(V\left(\mathrm{~m}^{3} \cdot \mathrm{m}^{-1}\right)\right)$ was calculated using the equation 3 below, using coastal displacement estimated from aerial photos and beach profile previously described:

$$
V=C_{d} *\left(h_{d}+h_{c}\right)
$$

where,

$C_{d}$ is the coastal displacement (m)

$h_{d}$ is the dune height $(\mathrm{m})$

$h_{c}$ is the depth of closure $(\mathrm{m})$

Sea-level rise scenarios were based on IPCC projections, where RCP (Representative Concentration Pathways) relate to the future climate scenarios based on concentration of greenhouse gases emissions (Table 1). The scenarios presented in IPCC are RCP 2.6, RCP 4.5, RCP 6.0 e RCP 8.5, where each scenario represents an increase in relation to pre-industrial levels - in heat quantity held in the atmosphere in the presence of greenhouse gases (that is: $+2.6,+4.5,+6.0$ e $8.5 \mathrm{~W} . \mathrm{m}^{-2}$, respectively). Present-day rates of sea-level rise considered in this study (Table 1) were based on historical sea-level rise measured in the last 40 years in Mar del Plata, Argentina (Church et al., 2013).

In this study four simulation experiments were run: i) historical sediment deficit only (under stable sea-level conditions); ii) historical sediment deficit under forecasted sea-level rise until the year 2100 based on RPC 2.6 (IPCC, 2014); iii) historical sediment deficit under forecasted sealevel rise until the year 2100 based on RPC8.5 (IPCC, 2014); and $i v$ ) historical sediment deficit under present day rates of sea-level rise. In order to stablish at what rate sealevel will take over control in coastal recession, further simulation experiments were performed using try and error methodology, where sea-level rise rate was altered and sediment budget was kept balanced ( $\mathrm{V}=0)$, up until mean coastal recession due to sea-level rise only, exceeded coastal recession due to historical sediment deficit only (from simulation $i$ ).

Each combination of parameters design required a separate simulation, that is, the combination of model-input parameters represented a unique simulation experiment (eg. $i$, ii, iii...). Model parameters were defined throughout the application of the stochastic approach allowing for the consideration of a range of parameter values represented by a PDF (Probability Density Function), which produces model simulation outputs that communicate uncertainty in a quantified and therefore more transparent way.

Although a variety of output parameters are available, this study focused on the distance by which the foredune receded inland (Recession distance, $R$ ) as the key indicator of coastal response or change. Each simulation experiment was repeated 2000 times to produce the output displayed as PDF for each experiment. Results produced by stochastic model simulations can be shown in the form of risk curves, which represent a transparent quantitative way of portraying uncertainty associated with such forecasts, which is not possible when applying deterministic models. Mean recession distances were plot on a regional map for clear visualization of coastal impacts (Figure 4).

\section{RESULTS}

Simulated mean shoreline recession distance for the year 2100 was higher when considering sea-level rise for IPCC scenario RCP8.5 combined with historical sediment deficit (RCP8.5+Sdef); followed by simulations considering sea-level rise scenario RCP2.6 also combined with sediment deficit (RCP2.6+Sdef); present day sea-level 


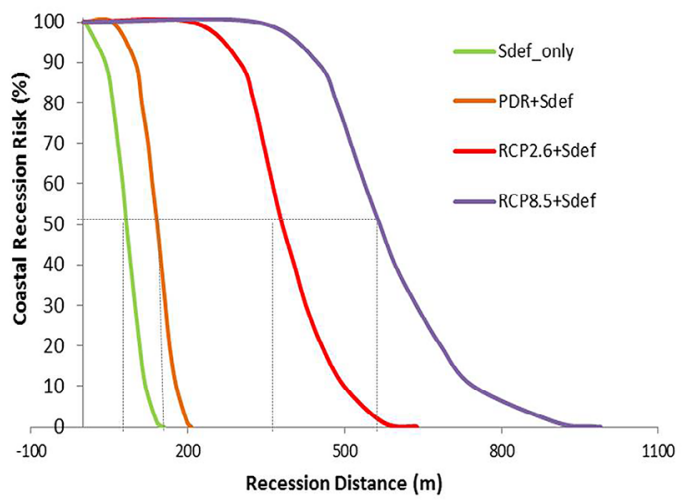

Figure 3. Risk-curve of projected recession distances for each simulated scenario.

rise rates with sediment deficit (PDR+Sdef); sediment deficit only (Sdef_only) (Figure 3 and Figure 4). These results indicated that both sea-level rise and sediment deficit caused the coast recession, and that their effects were amplified as they acted together. Nonetheless, it is clear that sediment deficit considered in simulations has greater impact in shoreline recession than the simulated present day sea-level rise rates.

Average shoreline recession distances ( $50 \%$ risk) from simulations under projected scenarios with different rates of sea-level rise (RPC2.6+Sdef and RPC 8.5+Sdef), both calibrated considering the same historical sediment deficit, were a factor of 2.7 and 4 times higher, respectively, than those considering average recession under present day sea-level rates calibrated with historical sediment deficit (PDR+Sdef) (Table 2).

By subtracting mean coastline recession values considering present day rates with historical sediment deficit (PDR+Sdef) from historical sediment deficit only (Sdef_only) it is possible to isolate each component. Simulation results showed that historical sediment deficit alone (Sdef only) produced erosion rates that exceeded those expected due to current sea-level rise alone (Table 2). These simulation results indicated that shoreline erosion problem along the sector of Hermenegildo Beach at present is mainly due to sediment deficit only, since sealevel is considered to be quasi-stable, currently rising at a very low rate. Projected mean shoreline position for each simulated scenario is displayed on Figure 4 and Table 2.

When considering the projected accelerated sea-level rise (RPC8.5 scenario) relative to sediment deficit only, it became clear that in the future overall coastal recession
(0.01-100\% risk) would be largely controlled by sea-level rise effects (Table 2; Figure 3 and Figure 4). Therefore, as sea-level rise rates increase in the future, there would be a change in the key driver of coastal change, intensification of coastal recession at Hermenegildo (Figure 4), when sediment budget would be less decisive (accounting for only $14 \%$ of mean recession). Mean coastal recession rates per year are displayed in table 2 .

Forecasted sea-level rise rates for the year 2100 in scenario RPC 8.5 are unprecedented and it is clear that if they become true, it will intensify erosion along the study area. Yet, a question that remained considering projected climate change conditions was: by how much sea-level has to rise in order to exceed sediment deficit effects and control coastal recession? After applying the try and error methodology, it was possible to determine that considering the projected sea-level rise used in this study, sea-level rise effects would control coastal recession at Hermenegildo Beach when it reached values around 1/6 of RPC8.5, with modal value of 0.12 , and lower and upper bounds of 0.09 and 0.16, respectively. Such sea-level values may be reached in 15 years (year 2033) considering RCP8.5 scenario.

\section{DISCUSSION}

Precise shoreline future position for management purposes are still very difficult to forecast. Subject to intrinsic uncertainty that still surrounds projections of sea-level rise and its impacts on coastal areas, they are far from exact. Nonetheless, they are not alone. Coastal sediment budget values even under present-day conditions are in most cases indirect estimates from modelling, or unknown. In this context, quantifying the effects of sediment budgets in coastal response becomes relevant at any scenario, and even more when forecasting coastal evolution under climate change context. Therefore, the results presented here for Hermenegildo Beach illustrates the relative importance of sea-level rise and sediment budgets in influencing contemporary and future coastal behaviour under the forecasted climatic conditions, which can be inferred for other locations subject to similar processes.

Sediment deficit (Sdef_only) is responsible for $58 \%$ of mean coastal recession along the study area under present day quasi-stable sea-level (PDR+Sdef) (Table 1, Figure 4), reinforcing the idea that under the current historical rates, sea-level is not the main responsible for 


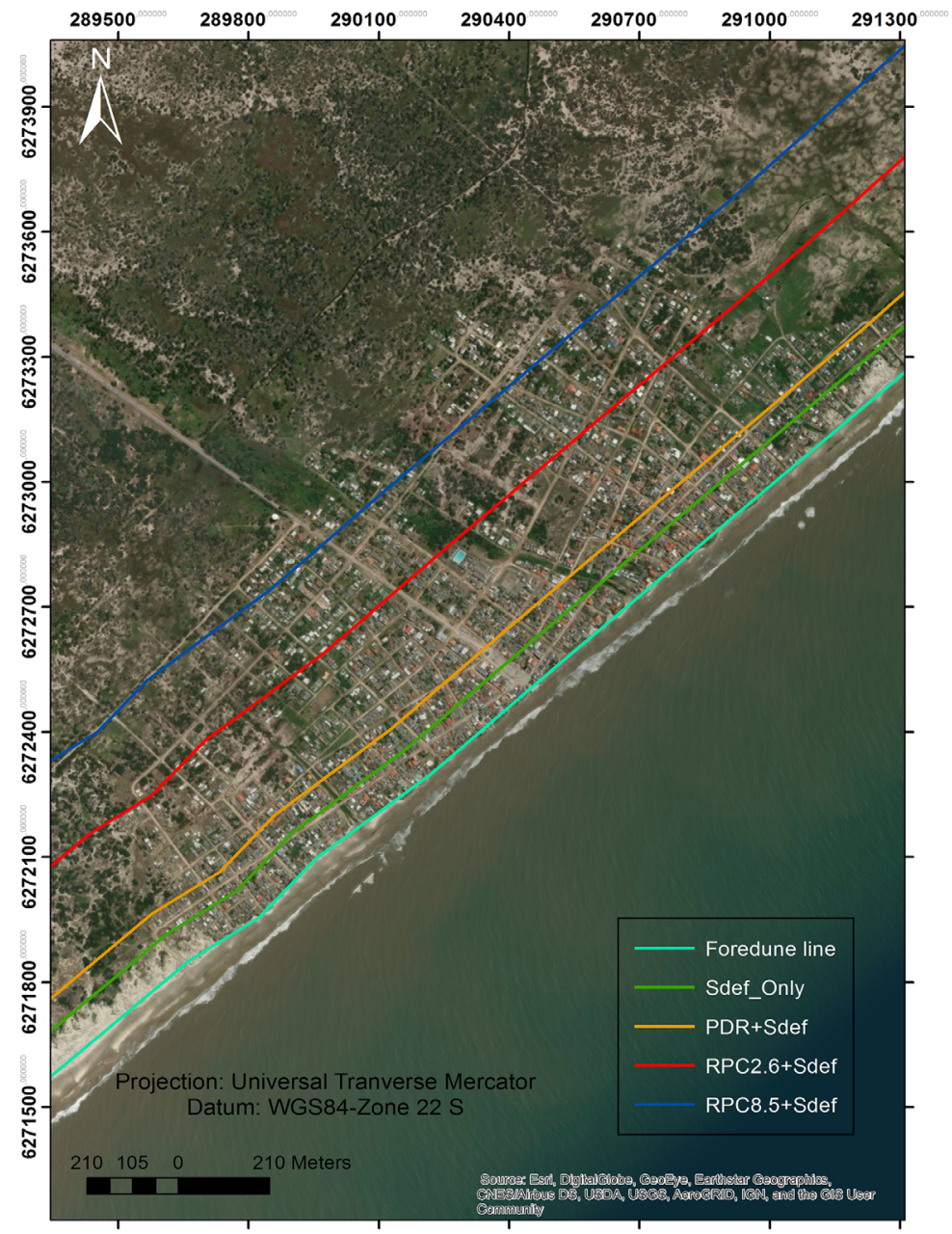

Figure 4. Projected recession distances for each simulated scenario for the year 2100 at the urbanized area of Hermenegildo Beach.

Table 2. Total mean coastal recession values and rates for each simulated scenario.

\begin{tabular}{lcc}
\hline Simulated Scenarios & $\begin{array}{c}\text { Mean Coastal recession }(\mathrm{m}) \\
(50 \% \text { erosion risk })\end{array}$ & Mean coastal recession rate $\left(m . y r^{l}\right)$ \\
\hline Sdef_only & 82 & 0.94 \\
PDR+Sdef & 141 & 1.6 \\
RPC2.6+Sdef & 380 & 4.3 \\
RPC8.5+Sdef & 567 & 6.5 \\
\hline
\end{tabular}

local erosion at Hermenegildo Beach. These results agree with Stive et al. (2009a) studies which show that during periods of near-still-stand sea-level conditions, such as those experienced during the late Holocene until present, Bruun-like effects due to sea-level rise were commonly overridden by the sediment budget component. That is, net natural shoreline changes are influenced by alongshore transport, as well as, cross-shore transport, which can sometimes exceed shoreline rates of change due to a rise in sea-level. For the Hermenegildo Beach region, such condition has been operating since the end of Postglacial Marine Transgression (6-7 cal Ka), when sea-level rise rates started decreasing and sediment deficit started 
exerting larger control over shoreline behavior causing the coastline to retreat (Lima et al., 2013).

Several studies have demonstrated the importance of sediment budgets in understanding coastal evolution in the long term and influencing shoreline position, demonstrating that better hindcasts of shoreline retreat were produced when this parameter was incorporated (List et al., 1997; Everts, 1985; Rosati, 2005; Brommer and Van Der Burgh, 2009). Likewise, Dillenburg et al.(2000) highlighted such role in coastal evolution along other parts of RS coast, for instance near Conceição Lighthouse, where shoreline had receded due to a negative sediment budget even during sea-level fall (0.35 mm. $\left.\mathrm{yr}^{-1}\right)$, nonetheless a quasi-stable sea-level condition. Similarly, the importance of sediment budget influence is also highlighted when despite the fact that sea-level was still rising at the end of Postglacial Marine Transgression, the embayed sectors along RS coast were accreting due to positive sediment budget, which surpassed sea-level rise effects (Dillenburg and Barboza, 2009a; Dillenburg et al., 2009b).

Comparatively, along the barrier islands of Louisiana, Sallenger et al. (1992) suggested that shoreline retreat under rising sea-levels was mainly linked to patterns of alongshore sediment transport and not sea-level rise. Analyses of the same coast undertaken by List et al. (1997) in 1930s and 1980s. An RMS difference criterion is employed to test whether an equilibrium profile form is maintained between survey years. Only about half the studied profiles meet the equilibrium criterion; this represents a significant limitation on the potential applicability of the Bruun rule. The profiles meeting the equilibrium criterion, along with measured rates of relative sea-level rise, are used to hindcast shoreline retreat rates at 37 locations within the study area. Modeled and observed shoreline retreat rates show no significant correlation. Thus, in terms of the Bruun approach, relative sea-level rise has no power for hindcasting (and presumably forecasting) further indicated that even under climate change conditions, depending on the rates of sea-level rise, the effects of alongshore sediment budgets played a major role in influencing shoreline behaviour. They showed that alongshore transport uncertainties overrode the effects of rising sea-levels, thus limiting the application of the Bruun rule (Stive et al., 2009b; White et al., 2005) principles when hindcasting shoreline position.

In addition, accurate estimates of sediment supply from the Columbia River and feeding from the lower shoreface have proved to be critical for barrier and beach sediment budget and therefore were essential in making reliable forecasts and hindcasts of large scale shoreline change (Ruggiero et al., 2010). As for the Rio Grande do Sul coast, a proper reconstruction of barrier evolution and shoreline position since the last Postglacial Marine Transgression until present was only achievable when taking into account the contribution from the alongshore sediment transport and onshore sediment supply from the shoreface, also highlighting the relevance of sediment budgets for large scale coastal behaviour and evolution (Dillenburg et al., 2000).

Conversely, when sea-level rise values increase, it starts controlling coastal recession. Simulation results point out that when the sea-level rise reaches values of $0.09,0.12$ and $0.16(\mathrm{~m})$, sea-level will become the main responsible factor influencing coastal recession. Therefore, under the simulated scenarios (RCP2.6 and RCP8.5), by the year 2100 when much higher levels will be achieved, the transgressive coastal behaviour installed will be primarily due to its effects. Those findings are in line with studies of Roy et al. (1994) which points out that under rapidly rising sea-level conditions, similar to those simulated using the RCP scenarios in this study, its effects became more important in influencing coastal change. According to them, under rapidly rising sea-levels variations in rates of coastal change between adjacent sectors were mainly influenced by substrate site morphology rather than local sediment budget.

\section{CONCLUSIONS}

This study presented a quantitative evaluation of the main controls influencing coastal change under the present and forecasted sea-level rise rates for the future. The intention here was not to present absolute projections of shoreline position, other than that, the efforts were towards clarifying the relative importance of sea-level and sediment budget in influencing coastal response under different rates of sea-level rise. In this context this study can bring light to the understanding the factors influencing erosion, which can be applied to other coastal sectors subjected to similar evolutional regimes, today and in climate change scenarios.

By simulating coastal response under variable sea-level rise rates and sediment budgets it was possible to quantify the influence of each of these parameters. Under presentday rates of sea-level rise, most of mean coastal recession (58\%) along Hermenegildo Beach sector is being caused by sediment deficit. On the other hand, when sea-level rise 
reaches the threshold of $0.09,0.12,0.16(\mathrm{~m})$ it will start to control coastal recession in this sector.

As for the forecasted sea-level rise rates for the year 2100 (RCP2.6+Sdef) and (RCP8.5+Sdef), it can be expected that coastal recession will be largely controlled by sea-level rise (79\% and $85 \%$, respectively), when sediment budget will play only a minor part in the overall coastal behavior ( $21 \%$ and $14 \%$, respectively). Mean coastal recession rates for each simulated scenario increased as sea-level rise rates escalate, displaying values of: 1.6 (m.yr $\left.{ }^{-1}\right)$ under present day rates (PDR+Sdef), 4.5 $\left(\mathrm{m} . \mathrm{yr}^{-1}\right)$ for one projected scenario (RCP2.6+Sdef), and 6.5 $\left(\mathrm{m} . \mathrm{yr}^{-1}\right)$ for the other (RCP8.5+Sdef).

\section{ACKNOWLEDGEMENTS}

The authors would like to thank CAPES (Coordenação de Aperfeiçoamento de Pessoal de Nível Superior) for providing the Post-doctoral Scholarship to Salette Amaral de Figueiredo. Thanks also to Peter Cowell at the University of Sydney for proving DRanSTM software.

\section{REFERENCES}

ALBUQUERQUE, M., ESPINOSA, J., TEIXEIRA, P., OLIVEIRA, A., CORREA, I. \& CALLIARI, L. 2013. Erosion or Coastal Variability: An Evaluation of the DSAS and the Change Polygon Methods for the Determination of Erosive Processes on Sandy Beaches. Journal of Coastal Research, 65, 17101714. DOI: $10.2112 / \mathrm{si} 65-289.1$

BROMMER, M. B. \& VAN DER BURGH, L. M. 2009. Sustainable Coastal Zone Management: A Concept for Forecasting Long-Term and Large-Scale Coastal Evolution. Journal of Coastal Research, 25, 181-188. DOI: 10.2112/07-0909.1

BRUUN, P. 1962. Sea-level Rise as a Cause of Shore Erosion. Journal of Waterways Harbors Division, American Society of Civil Engineers, 88, 117-130.

CHURCH, J., WHITE, N., HUNTER, J., MCINNES, K., COWELL, P. \& O'FARRELL, S. 2009. Sea-level Rise. In: NEWTON P. W. (ed.) Transitions: Pathways Towards Sustainable Urban Development in Australia. Collingwood: CSIRO Publishing, 191-209.

CHURCH, J.A., CLARK, P.U., CAZENAVE, A., GREGORY, J.M., JEVREJEVA, S., LEVERMANN, A., MERRIFIELD, M.A., MILNE, G.A., NEREM, R.S., NUNN, P.D., PAYNE, A.J., PFEFFER, W.T., STAMMER D. AND UNNIKRISHNAN, A.S., 2013. Sea Level Change. In: STOCKER, T.F., QIN, D., PLATTNER, G.-K., TIGNOR, M., ALLEN, S.K., BOSCHUNG, J., NAUELS, A., XIA, Y., BEX, V. and MIDGLEY, P.M. (eds.), Climate Change 2013: The Physical Science Basis. Contribution of Working Group I to the Fifth Assessment Report of the Intergovernmental Panel on Climate Change. Cambridge: Cambridge University Press, United Kingdom and New York, NY, USA, pp. 1137-1216.

COOPER, J. A. G. \& PILKEY, O. H. 2004. Sea-level rise and shoreline retreat: time to abandon the Bruun Rule. Global and Planetary Change, 43, 157-171. DOI: 10.1016/j.gloplacha.2004.07.001
COWELL, P. J., HANSLOW, D. J. \& MELEO, J. F. 1999. The shoreface. In: Short A. D. (ed.) Handbook of beach and shoreface morphodynamics. Chichester: John Wiley \& Sons, 379 p.

COWELL, P. J., ROY, P. S. \& JONES, R. A. 1992. Shoreface translation model: Computer simulation of coastal-sand-body response to sea level rise. Mathematics and computers in Simulation, 33, 603-608. DOI: doi.org/10.1016/0378-4754(92)90158-d.

COWELL, P. J., STIVE, M. J. F., NIEDORODA, A. W., SWIFT, D. J. P., VRIEND, H. J., BUIJSMAN, M. C., NICHOLLS, R. J., ROY, P. S., KAMINSKY, G. M., CLEVERINGA, J., REED, C. W. \& BOER, P. L. 2003b. The Coastal-Tract (Part 2): Applications of Aggregated Modeling of Lower-Order Coastal Change. Journal of Coastal Research, 19, 828-848.

COWELL, P. J., STIVE, M. J. F., NIEDORODA, A. W., VRIEND, H. J., SWIFT, D. J. P., KAMINSKY, G. M. \& CAPOBIANCO, M. 2003a. The Coastal-Tract (Part 1): A Conceptual Approach to Aggregated Modeling of Low-Order Coastal Change. Journal of Coastal Research, 19, 812-827.

COWELL, P. J., THOM, B. G., JONES, R. A., EVERTS, C. H. \& SIMANOVIC, D. 2006. Management of Uncertainty in Predicting Climate-Change Impacts on Beaches. Journal of Coastal Research, 22, 232-245.

COWELL, P. J. \& THOM, G. B. 2006. Reply to: Pilkey, O. H. and Cooper, A.G.,2006. Discussion of: Cowell et al., 2006. Management of Uncertainty in Predicting Climate-Change Impacts on Beaches, Journal of Coastal Research, 22(2), 232-245; Journal of Coastal Research, 22(6), 1577-1579. Journal of Coastal Research, 22, 1580-1584.

CUCHIARA, D. C., FERNANDES, E. H., STRAUCH, J. C., WINTERWERP, J. C. \& CALLIARI, L. J. 2009. Determination of the wave climate for the southern Brazilian shelf. Continental Shelf Research, 29, 545-555. DOI: 10.1016/j. csr.2008.09.025

CURRAY, R. J. 1964. Transgressions and regressions. In: MILLER, R. (ed.) Papers in Marine Geology. New York: MacMillan Press, p. 175-203.

DEAN, R.G., MAURMEYER, E.M., 1983. Models for beach profile response. In: P.D. Komar (Ed.), Handbook of Coastal Processes and Erosion. CRC Press, Boca Raton, FL, 151-166.

DECONTO, R. M. \& POLLARD, D. 2016. Contribution of Antarctica to past and future sea-level rise. Nature, 531, 591-597.

DILlENBURG, S. R. \& BARBOZA, E. G. 2009a. Long- and Short-term Progradation of a Regressive Barrier in the Southern Brazil. Journal of Coastal Research, 56, 599-601.

DILLENBURG, S. R., BARBOZA, E. G., TOMAZELLI, L. J., HESP, P. A., CLEROT, L. C. P. \& AYUP-ZOUAIN, R. N. 2009b. The Holocene Coastal barriers of Rio Grande do Sul. In: DILLENBURG, S. R. \& HESP, P. A. (eds.) Geology and geomorphology of Holocene Coastal Barriers of Brazil. Berlin: Springer, p. 53-91.

DILlENBURG, S. R., ROY, P. S., COWELL, P. J. \& TOMAZELLI, L. J. 2000. Influence of Antecedent Topography on Coastal Evolution as tested by the Shoreface Translation-Barrier model (STM). Journal of Coastal Research, 16, 71-81.

ESTEVES, L. S. 2004. Shoreline change and coastal evolution as parameters to identify priority areas for management in Rio Grande do Sul. Pesquisas em Geociências, 31, 15-30. 
EVERTS, C. H. (1985) "Sea level rise effects on shoreline position," Journal of Waterways, Port, Coastal Ocean Eng., 6(111), 985-999

FIGUEIREDO, S. A. 2013. Modelling climate change effects in southern Brazil. Journal of Coastal Research, 65, 1933-1938. DOI: $10.2112 /$ SI65-327.1

HALLERMEIER, R. J. 1981. A profile zonation for seasonal sand beaches from wave climate. Coastal Engineering, 4, 253-277. DOI: https://doi.org/10.1016/03783839(80)90022-8

IPCC; FIELD, C. B., BARROS, V. R., DOKKEN, D. J., MACH, K. J., MASTRANDREA, M. D., BILIR, T. E., CHATTERJEE, M., EBI, K. L., ESTRADA, Y. O., GENOVA, R. C., GIRMA, B., KISSEL, E. S., LEVY, A. N., MACCRACKEN, S., MASTRANDREA, P. R. \& WHITE, L. L. (eds.) (2014) IPCC, 2014: Climate change 2014: impacts, adaptation, and vulnerability. Part A: Global and Sectoral Aspects. Cambridge: Cambridge University Press. DOI: /10.1017/ cbo9781107415379

KINSELA, M. A., DALEY, M. J. A. \& COWELL, P. J. 2016. Origins of Holocene coastal strandplains in Southeast Australia: Shoreface sand supply driven by disequilibrium morphology. Marine Geology, 374, 14-30. DOI: 10.1016/j.margeo.2016.01.010

LIMA, L. G., DILLENBURG, S. R., MEDEANIC, S., BARBOZA, E. G., ROSA, M. L. C. C., TOMAZELLI, L. J., DEHNHARDT, B. A. \& CARON, F. 2013. Sea-level rise and sediment budget controlling the evolution of a transgressive barrier in southern Brazil. Journal of South American Earth Sciences, 42, 27-38. DOI: 10.1016/j.jsames.2012.07.002

LIST, J. H., SALLENGER, A. H., HANSEN, M. E. \& JAFFE, B. E. 1997. Accelerated relative sea-level rise and rapid coastal erosion: testing a causal relationship for the Louisiana barrier islands. Marine Geology, 140, 347-365. DOI: 10.1016/ S0025-3227(97)00035-2

MARTINHO, C. T., DILlENBURG, S. R. \& HESP, P. 2009. Wave Energy and Longshore Sediment Transport Gradients Controlling Barrier Evolution in Rio Grande do Sul, Brazil. Journal of Coastal Research, 25, 285-293. DOI: 10.2112/060645.1

MOLLER, O., LORENZZENTTI, J., STECH, J. AND MATA, M., 1996. The Patos Lagoon summertime circulation and dynamics. Continental Shelf Research, 16 (3), pp.335-351.

OPPENHEIMER, M. \& ALLEY, R. B. 2016. How high will the seas rise? Science, 354, 1375-1377. DOI: 10.1126/science. aak9460

PARISE, C. K., CALLIARI, L. J. \& KRUSCHE, N. 2009. Extreme storm surges in the south of Brazil: atmospheric conditions and shore erosion. Brazilian Journal of Oceanography, 57, 175-188. DOI: 10.1590/s1679-87592009000300002
PIANCA, C., MAZZINI, P. L. F. \& SIEGLE, E. 2010. Brazilian Offshore Wave Climate Based on NWW3 Reanalysis. Brazilian Journal of Oceanography, 58, 53-70. DOI: 10.1590/ s1679-87592010000100006

RAHMSTORF, S. 2007. A Semi-Empirical Approach to Projecting Future Sea-Level Rise. Science, 315, 368-370. DOI: 10.1126/science. 1135456

ROSATI, J. D. 2005. Concepts in Sediment Budgets. Journal of Coastal Research, 21, 307-322. DOI: 10.2112/02-475A.1

ROY, P. S., COWELL, P. J., FERLAND, M. A. \& THOM, B. G. 1994. Wave-dominated coasts. In: CARTER, R. W. C. \& WOODROFE, C. D. (eds.) Coastal evolution - Late Quaternary Morphodynamics. Cambridge: Cambridge University Press, 121-186. DOI: 10.1017/cbo9780511564420

RUGGIERO, P., BUIJSMAN, M., KAMINSKY, G. M. \& GELFENBAUM, G. 2010. Modeling the effects of wave climate and sediment supply variability on large-scale shoreline change. Marine Geology, 273, 127-140. doi: 10.1016/j.margeo.2010.02.008

SALLENGER, A. H., LIST, J. H., JAFFE, B. E., PENLAND, S. \& WILLIAMS, S. J. 1992. Regional coastal erosion research and beach preservation. In: Proceedings of the 5th National Conference on Beach Preservation Technology., Florida Shore Beach Preservartion Association, 115-134.

SIMEONI, U. \& CORBAU, C. 2009. Coastal vulnerability related to sea-level rise. Geomorphology, 107, 1-2. DOI: 10.1016/j.geomorph.2008.11.003

STIVE, M. J. F., COWELL, P. J. \& NICHOLLS, R. J. 2009a. Impacts of Global Environmental Change on Beaches, Cliffs and Deltas. In: SLAYMAKER, O., SPENCER, T. \& EMBLETON-HAMANN, C. (eds.) Geomorphology and Global Environmental Change. Cambridge: Cambridge University Press, 158-179. DOI: 10.1017/cbo9780511627057.007

STIVE, M. J. F., RANASINGHE, R. \& COWELL, P. J. 2009b. Sea-level Rise and Coastal Erosion. In: KIM, Y. C. (ed.) Handbook of Ocean and Coastal Engineering. Singapore: World Scientific Publishing. p.1023-1037. DOI: 10.1142/9789812819307_0037.

TOLDO JR, E. E., MARCHI DA MOTTA, L., EMÍLIO, L., DE ALMEIDA, D. S. B. \& NUNES, J. C. R. 2013. Large Morphological Change Linked To the Sediment Budget in the Rio Grande Do Sul Coast. In: $7^{\text {th }}$ International Conference on Coastal Dynamics, 1687-1696.

TOMAZELLI, L. \& WILLWOCK, J. 1992. Considerações Sobre o Ambiente Praial e a Deriva Litorânea de Sedimentos ao Longo do Litoral Norte do Rio Grande do Sul, Brasil. Pesquisas em Geosciências, 19, 3-12.

WHITE, N. J., CHURCH, J. A. \& GREGORY, J. M. 2005. Coastal and global averaged sea-level rise for 1950 to 2000. Geophysical Research Letters, 32, L01601. DOI: $10.1029 / 2004 \mathrm{gl} 021391$ 